\title{
CALIBRATION AND TESTING OF CS-CROPGRO MODEL FOR COMMON BEANS
}

Doi:http://dx.doi.org/10.1590/1809-4430-Eng.Agric.v36n6p1239-1249/2016

\section{MIQUÉIAS G. DOS SANTOS ${ }^{*}$, ROGÉRIO T. DE FARIA², LUIZ F. PALARETTI ${ }^{2}$, GEFFSON DE F. DANTAS ${ }^{2}$, ALEXANDRE B. DALRI ${ }^{2}$, ADRIANO DA S. LOPES ${ }^{3}$}

\author{
${ }^{1 *}$ Corresponding author. Universidade Estadual Paulista/ Jaboticabal - SP, Brasil. E-mail: miqueiassjp@ yahoo.com.br
}

\begin{abstract}
Simulation models of crop growth enable estimating crop yield and water balance components with low cost and high precision. This study aimed to calibrate and evaluate the performance of the CS-CROPGRO model for common beans under the conditions of Jaboticabal city (SP), Brazil. The model was calibrated and tested with data previously collected from two experiments conducted in 2002 and 2003. In these experiments, treatments corresponded to two irrigation scheduling methods (tensiometers and class A pan evaporation) and two cropping systems (conventional and no-till). For calibration, data from the experiment carried out in 2002 were used. For testing, we used data from the experiment conducted in 2003. By using the genetic coefficients calibrated for cultivar IAC-Carioca, the model could correctly simulate phenology, leaf area, dry matter and grain yield during both, calibration and testing, under no-till and conventional systems, combined with tensiometer and class A pan irrigation scheduling methods. Conversely, the model did not show the same performance for soil moisture simulations.
\end{abstract}

KEYWORDS: simulation, DSSAT, Phaseolus vulgaris, irrigation, planting system

\section{INTRODUCTION}

Despite the great importance for agricultural research, field experiments have great difficulties to be conducted given the time required or logistical difficulties. In addition, these studies are limited to answer promptly further questions generated, mainly involving weather and its interaction with crop production factors. In such a context, computer models are alternative tools to predict crop yields as function of weather conditions and crop and soil management practices instantly (OLIVEIRA et al., 2012).

Examples of such computer models are those included in the Decision Support System for Agrotechnology Transfer (DSSAT), which are able to simulate growth, development and water balance of different crops, in compliance with soil, plant and atmosphere characteristics (HOOGENBOOM et al., 2012).

Among these computer models, one includes the CS-CROPGRO, which enables simulating main physiological processes of several crop species. The model considers crop growth and development in a daily basis. It is a mechanistic and deterministic model that simulates the length of vegetative and reproductive stages, biomass accumulation and grain yield for a given cultivar, according to soil type, climatic conditions and management practice adopted. Specific crop coefficients (provided in a program file) and genetic coefficients of cultivars (calibrated for the genotype of interest) enable simulations of further responses of a given cultivar under varied environmental conditions.

In Brazil, the DSSAT software has been used to evaluate growth and production of crops such as common beans (OLIVEIRA et al., 2012; DALLACORT et al., 2011), cowpea beans (LIMA FILHO et al., 2013), soybeans (RODRIGUES et al., 2012; CHEVARRIA et al., 2013), corn (ALVES et al., 2011), sugarcane (NASSIF et al., 2012; MARIN et al., 2013; GOMES et al., 2014.), and perennial forages (PEDREIRA et al., 2011; LARA et al., 2012).

In crop models included in DSSAT, a single module is used to estimate water balance in the soil. In the literature, few studies are found regarding such model effectiveness to estimate the water

\footnotetext{
${ }^{2}$ Universidade Estadual Paulista/ Jaboticabal - SP, Brasil.

${ }^{3}$ Universidade Estadual de Mato Grosso do Sul/ Aquidauana - MS, Brasil.

Received in: 1-13-2016

Accepted in: 8-16-2016
} 
dynamics in soil, especially involving tillage systems (conventional and no-till). LIU et al. (2011) observed the ability of DSSAT in simulating soil moisture within surface layers, using the model for corn and soybeans.

Besides soil characteristics and climate data, DSSAT model application will require previous calibration of cultivar genetic coefficients, if it is unavailable in the system database. After calibration, its reliability has to be set through a validation process under the use conditions and with data different from those used in calibration.

The objective of this study was to calibrate and evaluate the performance of the CSCROPGRO model for common bean crop, test the water balance module under two sol tillage systems and two irrigation scheduling methods, under soil and climatic conditions of Jaboticabal city - SP, Brazil.

\section{MATERIAL AND METHODS}

Field data from two experiments, conducted in 2002 and 2003, were used to input the CSCROPGRO model. The experiments were conducted in Jaboticabal - SP (Brazil), at the geographical coordinates of $21^{\circ} 14^{\prime} 48^{\prime \prime} \mathrm{S}$ and $48^{\circ} 16^{\prime} 44^{\prime \prime} \mathrm{W}$, and average altitude of $557 \mathrm{~m}$. Local soil is classified as eutrophic Red Latosol - EUTRUDOX (Oxisol), clayey texture, A moderate horizon, kaolinitic hypoferric, on a gentle to corrugated relief. The regional climate is hot and humid tropical, with a rainy season between October and March, and dry between April and September. The local climatological normal from 1971 to 2000 is defined as average annual rainfall of 1,424 $\mathrm{mm}$, average annual temperature of $22.2{ }^{\circ} \mathrm{C}$ and relative humidity of $70.8 \%$.

The experimental design was randomized blocks in a $2 \times 2$ factorial with three blocks. The treatments consisted of two irrigation scheduling methods and two soil tillage systems: conventional till with tensiometer scheduling (CT-TENS), no-till with tensiometer scheduling (NTTENS), conventional till with class A pan evaporation (CT-CAP) and no-till with class A pan evaporation (NT-CAP).

Common beans (Phaseolus vulgaris, L) cultivar IAC-Carioca were sown on June 8, 2002 and on July 02,2003 , in rows spaced of $0.45 \mathrm{~m}$, and at densities of 31.2 and 41.4 seeds $\mathrm{m}^{-2}$ for the experiments in 2002 and 2003, respectively. The area was managed under crop succession of common beans in the winter and corn in the summer, under no-till (NT) and conventional till (CT). Average straw dry weight left from previous crop was of 2,000 kg ha-1 in 2002 and 3,500 $\mathrm{kg} \mathrm{ha}^{-1}$ in 2003 , incorporating $100 \%$ in conventional till up to a $20-\mathrm{cm}$ depth. Soil fertilization was accomplished according to chemical analysis of the soil and following crop recommendations. The other crop practices applied in the field experiments are found in LOPES (2006).

For calibration of the genetic coefficients, the GenSelect/ GenCalc application included in DSSAT system was used, using data from experimental treatments conducted in 2002. Model simulation testing using the calibrated genetic coefficients was performed by comparing the simulated values with independent data obtained in the experiment performed in 2003.

Model calibration was started with genetic coefficients of Carioca cultivar, available in the program, simulating the crop development throughout the same experimentation period. The process consisted in adjusting crop-related genetic coefficients to minimize gaps between stages flowering, first pod emergence and physiological maturity, simulated by the model, and observed experimentally. Afterwards, calibrations of genetic coefficient related to crop growth were carried out to match the estimates of dry mass and grain yields, leaf area index, and yield components (number of pods per plant, number of grains per pod and one grain mass) to the experimental data.

The agreement between observed and estimated data were made by the root mean square error (RMSE), according to [Eq. (1)] (WILLMOTT \& MATSUURA, 2005), correlation coefficient (R) according to [Eq. (2)], and mean error of estimates (MEE) according to [Eq. (3)]. The variables to be compared were leaf area index, total dry matter, grain yield, soil moisture within the depth ranges of 0-20 and 20-40 cm, in the experiment carried out in 2003 . 


$$
\begin{aligned}
& \text { RMSE }=\sqrt{\frac{\sum_{i=1}^{n}(\mathrm{Pi}-\mathrm{Oi})^{2}}{\mathrm{n}}} \\
& \mathrm{R}=\frac{\sum_{\mathrm{i}=1}^{\mathrm{n}}(\mathrm{Oi}-0)(\mathrm{Pi}-\mathrm{P})}{\sqrt{\left(\sum_{\mathrm{i}=1}^{\mathrm{n}}(\mathrm{Oi}-\mathrm{O})^{2}\right)\left(\sum_{\mathrm{i}=1}^{\mathrm{n}}(\mathrm{Pi}-\mathrm{P})^{2}\right)}} \\
& \text { MEE }=\frac{\sum_{i=1}^{n}(\mathrm{Oi}-\mathrm{P})^{2}}{\mathrm{n}}
\end{aligned}
$$

In which:

$\mathrm{Pi}$ is the value estimated by the model;

Oi is the value observed experimentally;

$\mathrm{n}$ is the number of observations;

$P$ is the arithmetic mean of the estimated values, and

0 the arithmetic mean of the observed values.

\section{RESULTS AND DISCUSSION}

Seasonal temperature patterns were similar in both years, averaging 21.8 and $21.9{ }^{\circ} \mathrm{C}$ in 2002 and 2003, respectively (Figure 1). As usual, crop water demand were not met by local rainfall in both growing years. The annual rainfall totals were $166 \mathrm{~mm}$ in 2002 and $82 \mathrm{~mm}$ in 2003.

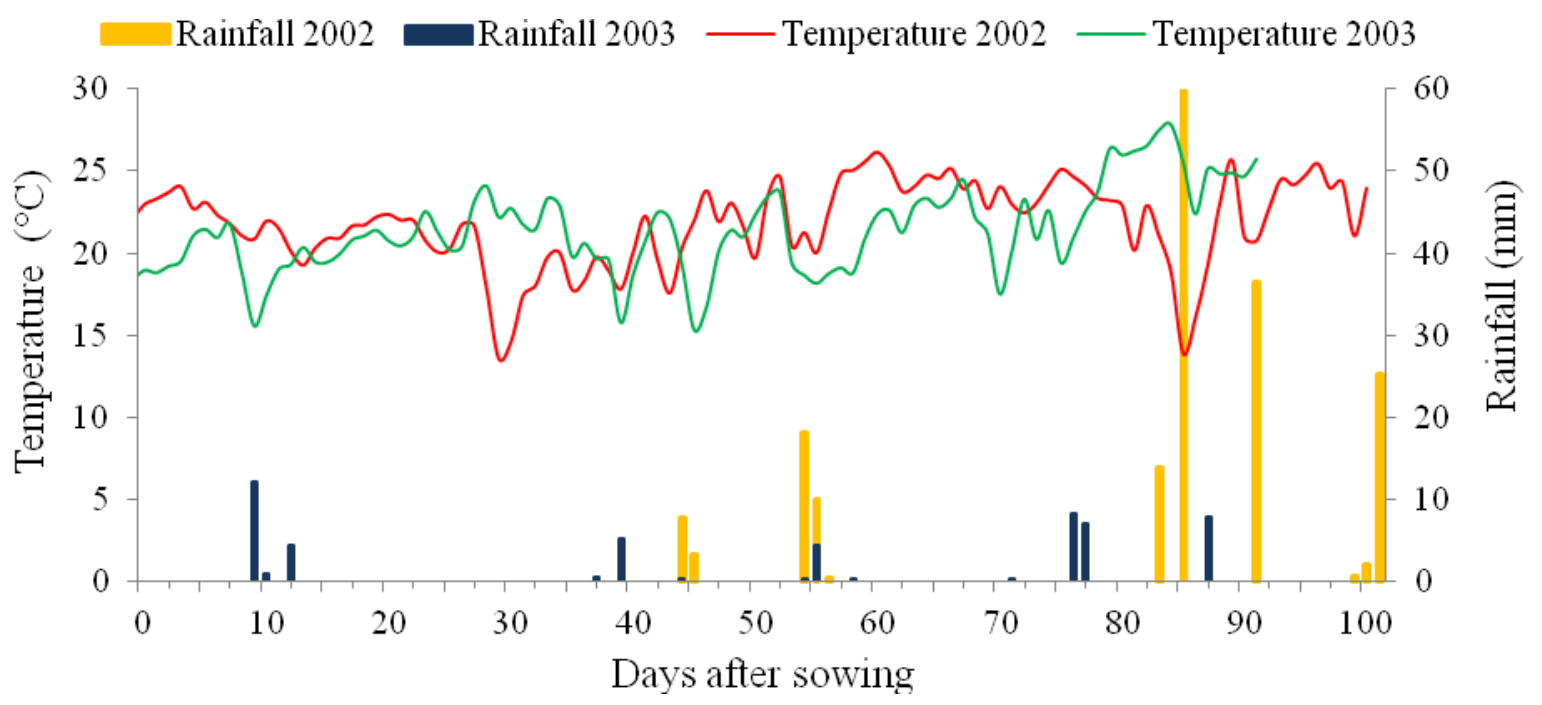

FIGURE 1. Mean temperature and rainfall during 2002 and 2003 crop seasons, in Jaboticabal, SP (Brazil).

\section{Model calibration}

The calibrated genetic coefficients used in the CS-CROPGRO model for IAC-Carioca cultivar are shown in Table 1. By assuming cultivar photoperiod insensitivity (PPSEN $=0$ ), thermal time required to achieve flowering from emergence (EM-FL) was calibrated in photothermal days (ptd) as 24 ptd. From flowering to the onset of the first pod (FL-SH), the requirement was 6 ptd, up to the first seed (FL-SD) it was 18 ptd, until pod addition (PODUR) equal 10 ptd, and to the end of leaf growth (FL-LF) equal 30 ptd. The seed feeling duration period (SFDUR) and the period for physiological maturity since first seed (SD-PM) were of 20 and 16 ptd, respectively. The coefficients corresponding to leaf characteristics were equal to $300 \mathrm{~cm}^{2} \mathrm{~g}^{-1}$ for maximum leaf area (SLAVR), and of $133 \mathrm{~cm}^{2}$ for specific leaf area (SIZLF). In addition, it was assumed IAC-Carioca 
cultivar has a photosynthetic efficiency (LFMAX) of $1.0 \mathrm{mg} \mathrm{CO}_{2} \mathrm{~m}^{-2} \mathrm{~s}^{-1}$, unit seed weight (WTPSD) of $0.275 \mathrm{~g}$, with mean seed number per pod (SDPDV) equal to 4 . Finally, a maximum fraction of daily growth shared between seeds and pods (XFRT) were set equal to one.

TABLE 1. Genetic coefficients used to calibrate CS-CROPGRO model for common beans IACCarioca cultivar.

\begin{tabular}{cccccccc}
\hline Cultivar & CSDL & PPSEN & EM-FL & FL-SH & FL-SD & SD-PM & FL-LF \\
IAC-Carioca & 12.17 & 0.0 & 24.0 & 6.0 & 18.0 & 16.0 & 30.0 \\
LFMAX & SLAVR & SIZLF & XFRT & WTPSD & SFDUR & SDPDV & PODUR \\
1.00 & 300 & 133.0 & 1.00 & 0.275 & 20.0 & 4.0 & 10.0 \\
\hline
\end{tabular}

CSDL - critical day length, above which reproductive development is not affected (h); PPSEN - plant response to photophase over time $\left(1 \mathrm{~h}^{-1}\right)$; EM-FL - period between plant emergence and the onset of the first flower (R1) (photothermal days); FL-SH - period between the onset of the first flower and the appearance of the first pod (R3) (photothermal days); FL-SD - period between the onset of the first flower and the start of seed formation (R5) (photothermal days); SD-PM - period between the start of seed formation and physiological maturity (R7) (photothermal days); FL-LF - period between the onset of the first flower (R1) and the end of leaf expansion; LFMAX - maximum leaf photosynthesis rate at an optimal temperature of $30^{\circ} \mathrm{C}$; SLAVR - specific leaf area under standard growth conditions $\left(\mathrm{cm}^{2}\right)$; SIZLF - maximum size of a completely expanded leaf $\left(\mathrm{cm}^{2}\right)$; XFRT - maximum fraction of daily growth shared between seeds and pods; WTPSD - maximum weight per seed (g); SFDUR - duration of grain swelling period in pods under standard growth conditions (photothermal days); SDPDV - mean seeds per pod under standard growth conditions; PODUR time required for a cultivar to reach ideal pod conditions (photothermal days)

Because of low temperatures during crop cycle, in order to improve estimates of flowering date the coefficients OPTBI and SLOBI- 1 were adjusted to $20{ }^{\circ} \mathrm{C}$ and $0.05{ }^{\circ} \mathrm{C}$, respectively. OPTBI corresponds to the minimum temperature above which there is no delaying effect on the period between emergence and flowering; yet SLOBI stands for the delay in phenological phases by temperature unit below the one set for OPTBI. FARIA et al. (2002) had also adopted this procedure to simulate properly the length of vegetative phase in common beans grown in Paraná state during winter.

The model correctly estimated the crop cycle length as well as the dates of phenological stages (Table 2). The simulated and the observed dates coincided satisfactorily. The flowering was estimated as 54 days after sowing (DAS), the onset of the first pod as 61 DAS and the physiological maturity as 96 DAS. Other studies had already proved the ability of this model in simulating the phenology of other cultivars of beans, corroborating our findings (MEIRELES et al., 2002; OLIVEIRA et al., 2012).

TABLE 2. Number of days required for the occurrence of bean phenological stages, observed and simulated by CS-CROPGRO model for the calibration phase.

\begin{tabular}{|c|c|c|c|c|c|c|}
\hline \multirow{2}{*}{ Treatment } & \multicolumn{2}{|c|}{ Flowering } & \multicolumn{2}{|c|}{ First Pod } & \multicolumn{2}{|c|}{ Physiological Maturity } \\
\hline & $\mathrm{O}$ & $\mathrm{S}$ & $\mathrm{O}$ & $\mathrm{S}$ & $\mathrm{O}$ & $\mathrm{S}$ \\
\hline CT-TENS & 54 & 54 & 61 & 61 & 96 & 95 \\
\hline NT-TENS & 54 & 54 & 61 & 61 & 96 & 95 \\
\hline CT-CAP & 54 & 54 & 61 & 61 & 96 & 96 \\
\hline NT-CAP & 54 & 54 & 61 & 61 & 96 & 96 \\
\hline
\end{tabular}

$\mathrm{O}$ - observed; $\mathrm{S}$ - simulated

Through the statistical indices shown in Figure 2, there was a good fit for leaf area between the simulated and the observed data, in all treatments. The magnitude of the errors, expressed in RMSE, presented results between $0.70 \mathrm{~m}^{2} \mathrm{~m}^{-2}$ to $1.01 \mathrm{~m}^{2} \mathrm{~m}^{-2}$, indicating a high accuracy of the simulation. The model also showed good accuracy with R-values ranging from 0.86 to 0.87 . Moreover, regressions showed low deviations as inferred by MEE values, between 0.11 and $0.79 \mathrm{~m}^{2}$ $\mathrm{m}^{-2}$. 


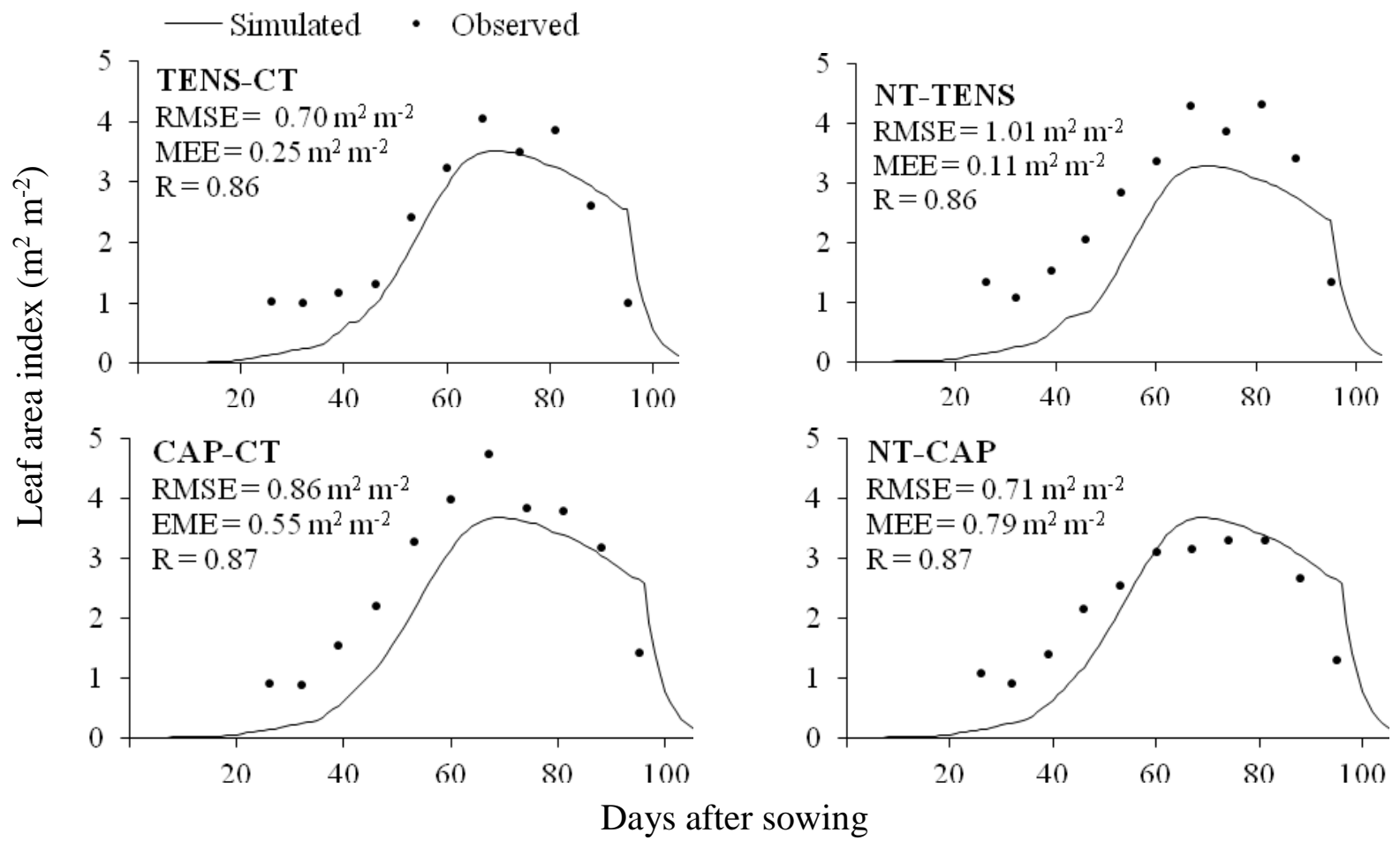

FIGURE 2. Leaf area index of common beans, field-observed data vs. simulated data for the calibration phase of CS-CROPGRO model.

Dry mass simulations were also quite accurate with RMSE values ranging from $1,031 \mathrm{~kg} \mathrm{ha}^{-1}$ to $1,659 \mathrm{~kg} \mathrm{ha}^{-1}$ (Figure 3). These simulations had low deviations compared to field observations, with a maximum MEE of $1,320 \mathrm{~kg} \mathrm{ha}^{-1}$. Furthermore, the model properly predicted field crop grown, with R-values between 0.96 and 0.99 . Dry matter yields were underestimated by about $21 \%$, 24\%, 26\% and 23\%, for all treatments CT-TENS, NT-TENS, CT-CAP and NT-CAP, respectively. The simulated maximum value $\left(5,914 \mathrm{~kg} \mathrm{ha}^{-1}\right)$ took place in NT-CAP treatment, at 96 DAS; however, the most productive treatment in the field was CT-CAP, with 7,977 $\mathrm{kg} \mathrm{ha}^{-1}$, at $88 \mathrm{DAS}$.

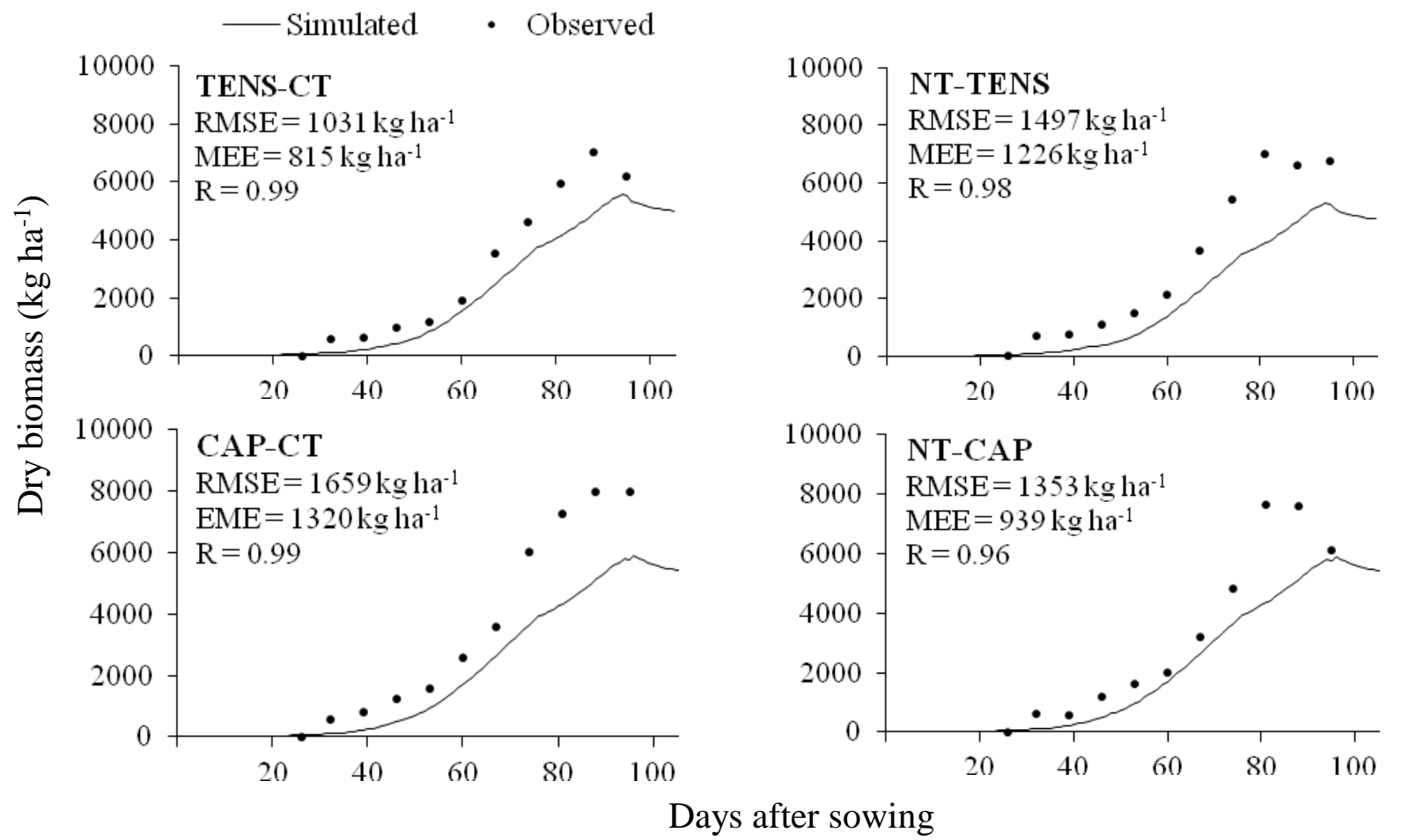

FIGURE 3. Dry biomass of common beans, field-observed data vs. simulated data for the calibration phase of CS-CROPGRO model. 
Table 3 demonstrates that the model simulated adequately crop yield, with maximum variation of $5.0 \%$, reflecting the accuracy occurred in model calibration. OLIVEIRA et al. (2012), calibrating the same model for different bean cultivars, found variations of up to $15.94 \%$ between simulated and field-observed yields.

TABLE 3. Grain yield of common beans, field-observed data vs. simulated data by CS-CROPGRO, for the calibration phase.

\begin{tabular}{ccccc}
\hline \multirow{2}{*}{ Treatment } & Simulated & Observed & Deviation & \\
\cline { 2 - 4 } & & $\left(\mathrm{kg} \mathrm{ha}^{-1}\right)$ & & Deviation $(\%)$ \\
\cline { 2 - 4 } \cline { 3 - 4 } CT-TENS & 2311 & 2397 & -86 & -3.6 \\
NT-TENS & 2225 & 2342 & -117 & -5.0 \\
CT-CAP & 2594 & 2630 & -36 & -1.4 \\
NT-CAP & 2593 & 2471 & 122 & 4.9 \\
\hline
\end{tabular}

$\%=[($ Simulated - Observed $) /$ Observed $] \times 100$

\section{Model testing}

As in calibration phase, the model was also precise to estimate the length of crop cycle (Table 4). However, the dates of flowering and onset of the first pod were underestimated. By the model, flowering occurred at 59 DAS, while in the field it was at 72 DAS. The first pod appearance was simulated as 67 DAS, but in the field, it was at 79 DAS. Such discrepancy between the data can be explained by inaccuracy of the model or even, by the way field observations were carried out. In field, evaluations were visually made, so it was assumed a given phenological stage if $50 \%$ of the plants had at least one flower or pod.

TABLE 4. Number of days required for each phenological stage of common beans, field-observed data vs. simulated data by CS-CROPGRO model for the testing phase.

\begin{tabular}{|c|c|c|c|c|c|c|}
\hline \multirow{2}{*}{ Treatment } & \multicolumn{2}{|c|}{ Flowering } & \multicolumn{2}{|c|}{ First Pod } & \multicolumn{2}{|c|}{ Physiological Maturity } \\
\hline & $\mathrm{O}$ & $\mathrm{S}$ & $\mathrm{O}$ & $\mathrm{S}$ & $\mathrm{O}$ & $\mathrm{S}$ \\
\hline CT-TENS & 72 & 59 & 79 & 67 & 100 & 100 \\
\hline NT-TENS & 72 & 59 & 79 & 67 & 100 & 100 \\
\hline CT-CAP & 72 & 59 & 79 & 67 & 100 & 100 \\
\hline NT-CAP & 72 & 59 & 79 & 67 & 100 & 100 \\
\hline
\end{tabular}

O- observed; $\mathrm{S}$ - simulated

The model properly simulated leaf area index (Figure 4), as given by RMSE of $0.96 \mathrm{~m}^{2} \mathrm{~m}^{-2}$ (NT-TENS) to $1.19 \mathrm{~m}^{2} \mathrm{~m}^{-2}$ (CT-TENS). The R-values ranged from 0.86 (NT-CAP) to 0.96 (CTCAP), and MEE reached a maximum of $-1.08 \mathrm{~m}^{2} \mathrm{~m}^{-2}$ for CT-TENS, but in the other treatments values were up to $0.38 \mathrm{~m}^{2} \mathrm{~m}^{-2}$.
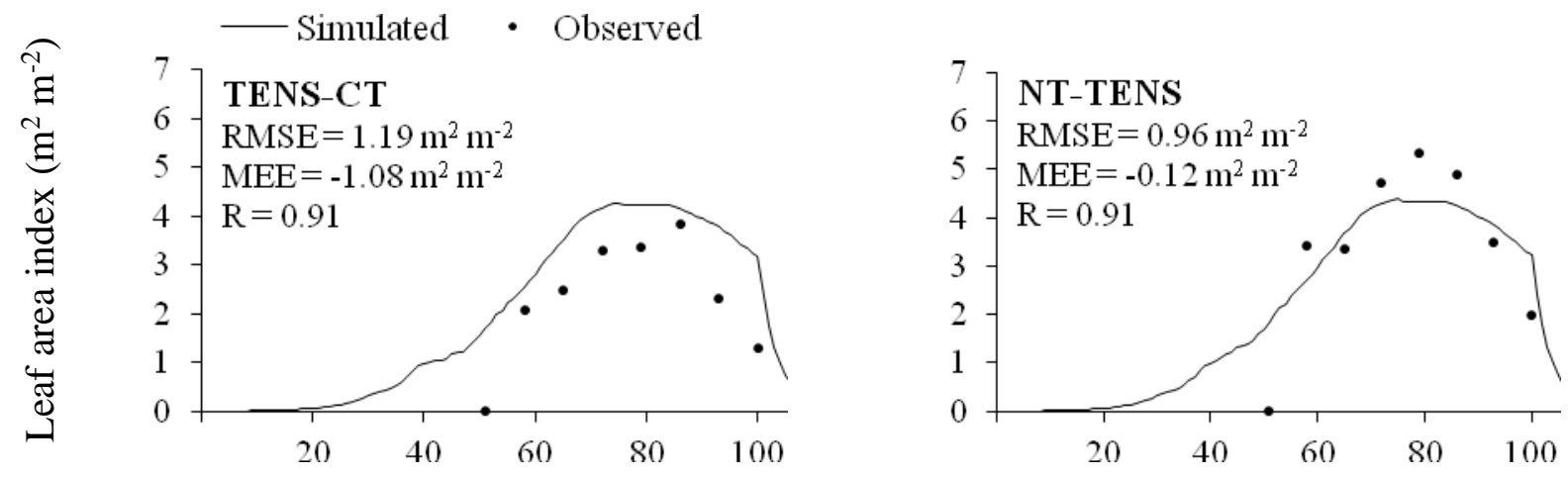

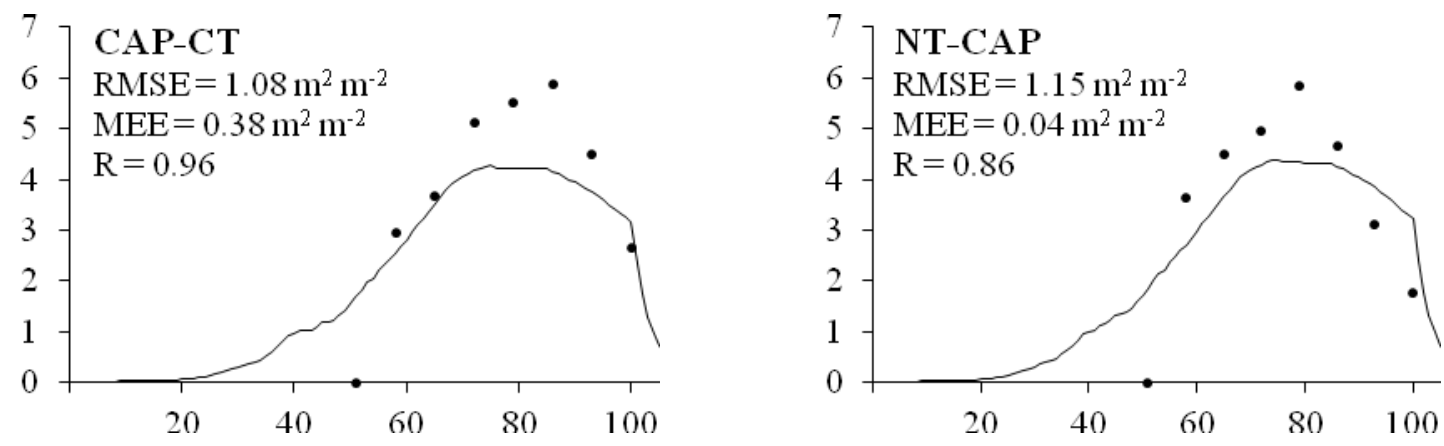

Days after sowing

FIGURE 4. Leaf area index of common beans, field-observed data vs. simulated data by CSCROPGRO model for the testing phase.

The highest leaf area index (LAI) was estimated for a treatment under no-till $\left(4.39 \mathrm{~m}^{2} \mathrm{~m}^{-2}\right)$ at 75 DAS. It was underestimated by $26 \%$ compared to the experimentally observed, which occurred at 86 DAS $\left(5.89 \mathrm{~m}^{2} \mathrm{~m}^{-2}\right)$. On the other hand, lowest estimate $\left(4.27 \mathrm{~m}^{2} \mathrm{~m}^{-2}\right)$ was simulated under conventional till, also at 75 DAS, overestimating by $22 \%$ the field observation $\left(3.82 \mathrm{~m}^{2} \mathrm{~m}^{-2}\right.$ at 86 DAS). These results are superior those found by DALLACORT et al. (2011), who observed a maximum simulated LAI of $2.55 \mathrm{~m}^{2} \mathrm{~m}^{-2}$, testing the correlation between CS-CROPGRO estimates and field observations conducted at various planting dates, in the city of Maringa - PR (Brazil). In another study, DALLACORT et al. (2005) studied different planting dates of beans, and observed a maximum LAI of $3.34 \mathrm{~m}^{2} \mathrm{~m}^{-2}$ during the best growing season. However, these results are lower than those observed by MEIRELES et al. (2002), who found IAFs of up to $6.47 \mathrm{~m}^{2} \mathrm{~m}^{-2}$ in simulations.

The accumulated dry mass was underestimated by the model for all treatments except the CTTENS (Figure 5), however, the simulations follow the course of observed data during the crop cycle. Thus, similarly for the variables previously analyzed, the parameterization of the genetic coefficients was suitable, as given by maximum values for RMSE of 1,613 kg ha-1, MEE of 1,335 $\mathrm{kg} \mathrm{ha}^{-1}$, and $\mathrm{R}$-values ranging from 0.91 to 0.95 .

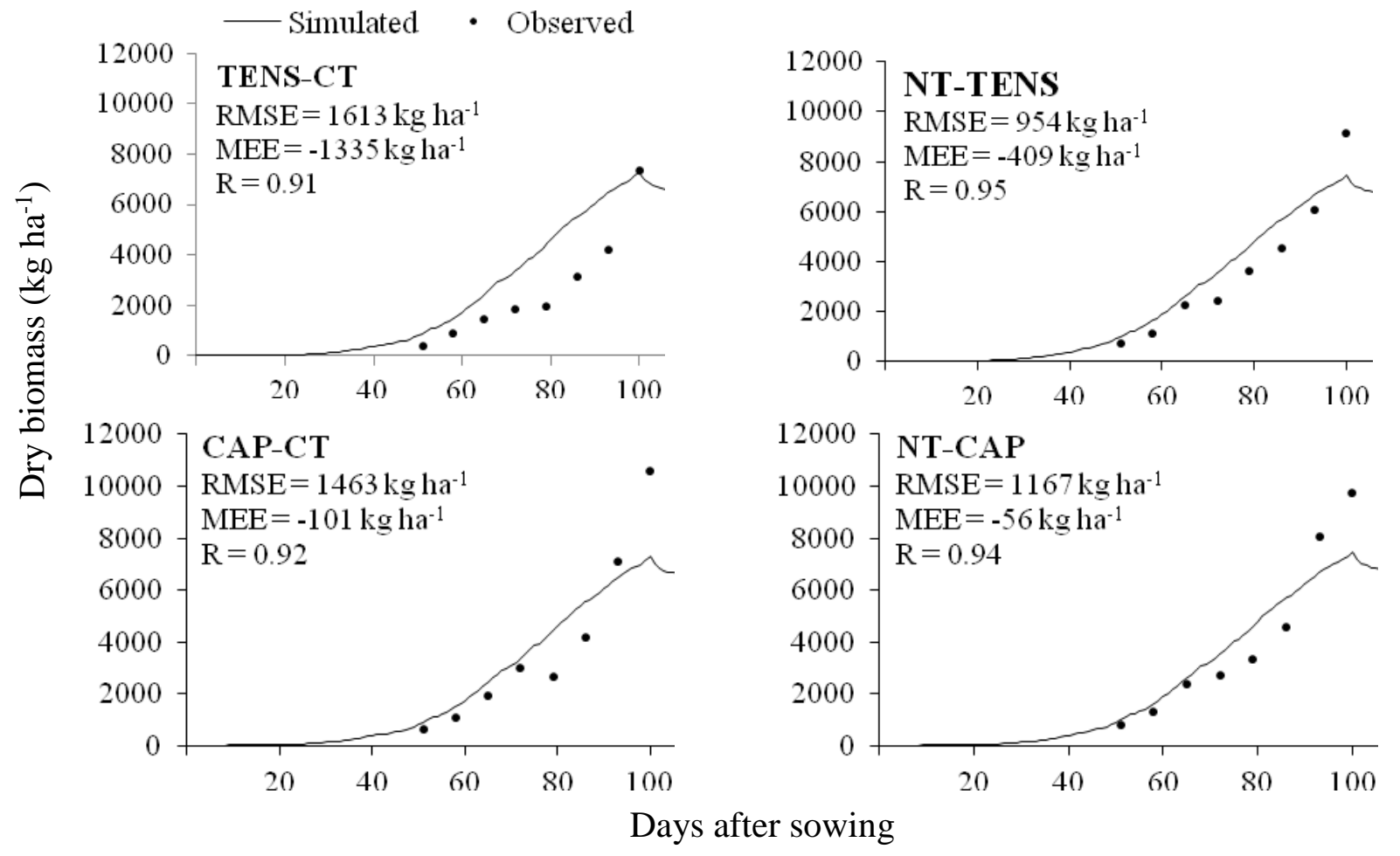

FIGURE 5. Dry biomass of common beans, field-observed data vs. simulated data by CSCROPGRO model for the testing phase. 
The largest estimates of dry matter production were found under NT, reaching 7,466 kg ha-1 at 100 DAS, regardless of irrigation scheduling method. In field, CT-CAP and CT-TENS showed the highest and lowest biomass production, reaching yields of $10,614 \mathrm{~kg} \mathrm{ha}^{-1}$ and $7,345 \mathrm{~kg} \mathrm{ha}^{-1}$, respectively, also at 100 DAS. The variations between simulated and observed values were of $0.9 \%$, $18.5 \% 31.4 \%$ and $23.2 \%$, for CT-TENS, NT-TENS, CT-CAP and NT-CAP, respectively. Yet, these values are higher than the ones reported by DALLACORT et al. (2005), in which it was simulated an amount of $4,423 \mathrm{~kg} \mathrm{ha}^{-1}$ for the best growing season in the Midwestern of the Paraná state.

Grain yield estimates were close to the observed values, except in CT-TENS, which was overestimated in $51.6 \%$ by the model, when compared to field observation (Table 5). For the other treatments, there was a high correlation from estimates to the field-observed data, with variations of $2.0 \%, 16.7 \%$ and $3.9 \%$ for NT-TENS, CT-CAP and NT-CAP, respectively, thus highlighting the ability of the model to simulate crop yield.

TABLE 5. Grain yield of common beans, field-observed data vs. simulated data by CS-CROPGRO model during the testing phase.

\begin{tabular}{|c|c|c|c|c|}
\hline Treatment & Simulated & $\begin{array}{l}\text { Observed } \\
\left(\mathrm{kg} \mathrm{ha}^{-1}\right)\end{array}$ & Deviation & $\begin{array}{c}\text { Deviation } \\
(\%)\end{array}$ \\
\hline CT-TENS & 2829 & 1866 & 963 & 51.6 \\
\hline NT-TENS & 2861 & 2805 & 56 & 2.0 \\
\hline CT-CAP & 2829 & 3394 & -565 & -16.7 \\
\hline NT-CAP & 2861 & 2754 & 107 & 3.9 \\
\hline
\end{tabular}

$\%=[($ Simulated - Observed $) /$ Observed $] \times 100$

DALLACORT et al. (2005) simulated yield of common beans Carioca cultivar, and found a range of 2,127 $\mathrm{kg} \mathrm{ha}^{-1}$ to $3,197 \mathrm{~kg} \mathrm{ha}^{-1}$. Likewise, MEIRELES et al. (2002), calibrating and testing the model CS-CROPGRO for Carioca beans at varied planting row spacing and fertilizer doses, observed that simulations surpassed experimental data in $10.8 \%$ to $15.4 \%$. In turn, DALLACORT et al. (2011) found a variation of up to $29 \%$.

The model presented low accuracy in estimating soil moisture (Figure 6) with R-values reaching up to 0.55 . There was a large gap between simulated mean values and field observations, with MEE of up to $0.21 \mathrm{~m}^{3} \mathrm{~m}^{-3}$. Regarding accuracy, the simulation showed a low degree of proximity to the field values, evidenced by RMSE values that ranged from $0.014 \mathrm{~m}^{3} \mathrm{~m}^{-3}$ until 0.037 $\mathrm{m}^{3} \mathrm{~m}^{-3}$. Overall, the model underestimated the experimentally observed values.

Using CS-CROPGRO to simulate soil moisture in common beans, DALLACORT et al. (2010) found correlation coefficients of 0.70 and 0.74 . Nonetheless, they still point out for differences between predictions and values measured in field with TDR. In line with this, other published reports have associated such discrepancy to inefficiency of the model in predicting water absorption and redistribution throughout the soil (FARIA \& BOWEN, 2003; DALLACORT et al., 2011).

Despite the discrepancies, particularly between soil moisture simulations and field observations, the statistical indices, chosen for CS-CROPGRO testing, indicate that it can be used for phenology estimates and yield of common beans under different water systems and tillage management. It enables using the model, supplied by genetic coefficients of IAC-Carioca cultivar, for predicting growth and yield in long-term simulations to foresee crop risks related to climatic variables. 
- Simulated $\rightarrow$ Observed

TENS-CT 0-20 cm

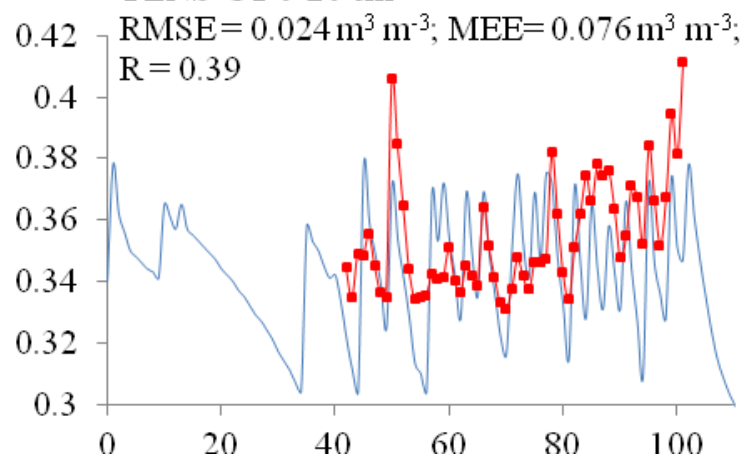

TENS-CT 20-40 cm

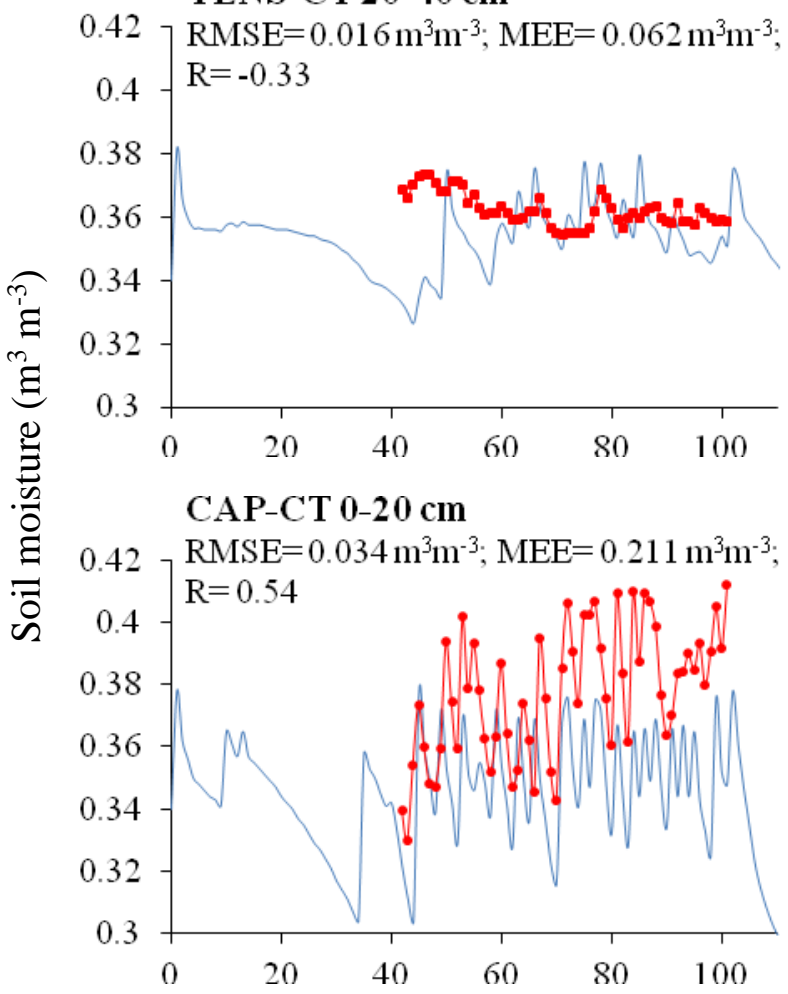

CAP-CT 20-40 cm

0.42 RMSE $=0.017 \mathrm{~m}^{3} \mathrm{~m}^{-3} ; \mathrm{MEE}=0.072 \mathrm{~m}^{3} \mathrm{~m}^{-3}$;

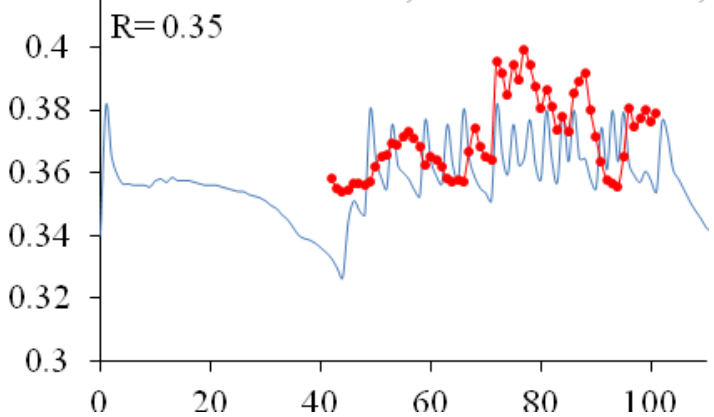

NT-TENS 0-20 cm

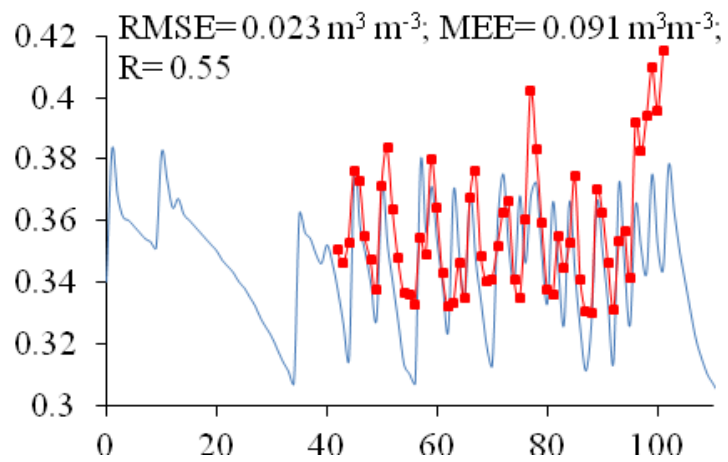

NT-TENS 20-40 cm

0.42 RMSE $=0.014 \mathrm{~m}^{3} \mathrm{~m}^{-3} ; \mathrm{MEE}=0.014 \mathrm{~m}^{3} \mathrm{~m}^{-3}$;

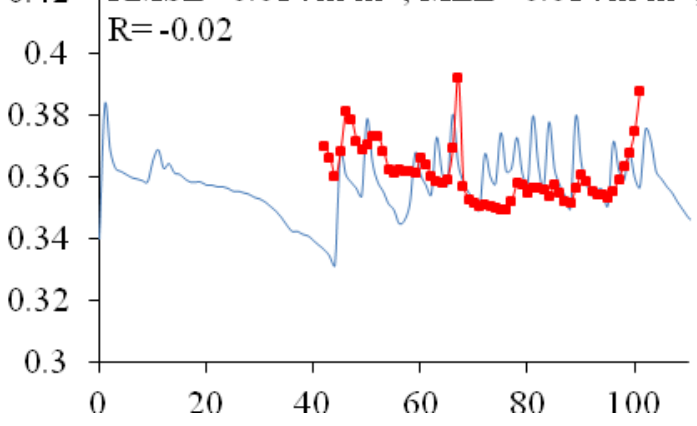

NT-CAP 0-20cm

$0.42 \mathrm{RMSE}=0.037 \mathrm{~m}^{3} \mathrm{~m}^{-3} ; \mathrm{MEE}=0.211 \mathrm{~m}^{3} \mathrm{~m}^{-3}$;

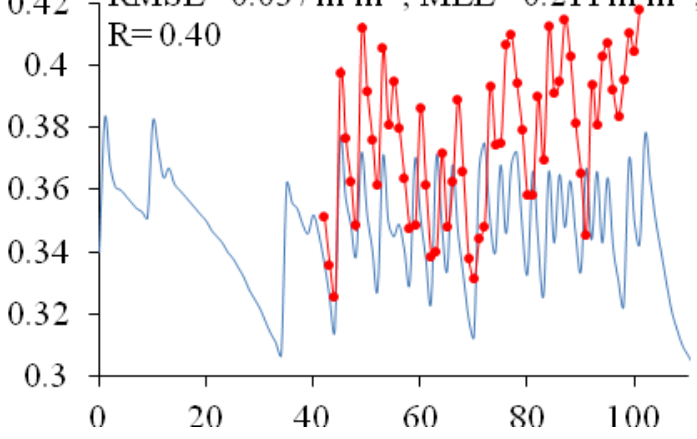

NT-CAP 20-40 cm

$0.42 \mathrm{RMSE}=0.026 \mathrm{~m}^{3} \mathrm{~m}^{-3} ; \mathrm{MEE}=0.167 \mathrm{~m}^{3} \mathrm{~m}^{-3}$;

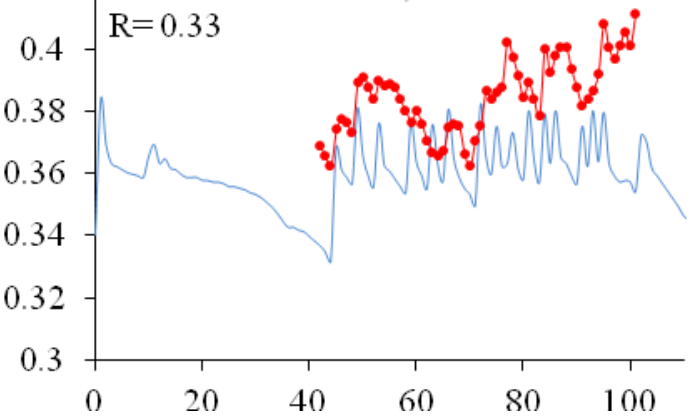

Days after sowing

FIGURE 6. Soil moisture in the layers of $0-20$ and $20-40 \mathrm{~cm}$ depth, field-observed data vs. simulated data by CS-CROPGRO model. CT-TENS: conventional till and tensiometer; NT-TENS: no-till and tensiometer; CT-CAP: conventional till and class A pan; and NT-CAP: no-tillage and class A pan. 


\section{CONCLUSIONS}

The calibrated model could satisfactorily simulate phenology, leaf area, dry matter and grain yield during calibration and testing, for common beans grown under no-till and conventional till systems, combined with irrigation scheduling with tensiometer and class A pan.

The fitting between simulations and soil moisture field-observations did not show the same performance as the other variables.

\section{REFERENCES}

ALVES, M.E.B.; ANDRADE, C.L.T.; CÁRDENAS, R.R.; AMARAL, T.A.; SILVA, D.F. Identificação e quantificação do efeito de fatores ambientais na produtividade da cultura do milho na região de JANAÚBA, MG. Revista Brasileira de Agricultura Irrigada, Fortaleza, v.5, n. 3, p.188- 201, 2011.

CHEVARRIA, V.V.; DEL PONTE, E.M.; JAHNKE, S.M. Número de gerações de um percevejo e seu parasitoide e da severidade da ferrugem asiática em soja, simulados em cenários de clima e manejo no norte do RS. Ciência Rural, Santa Maria, v.43, n.4, p.571-578, 2013.

DALLACORT, R.; FREITAS, P.S.L. de; FARIA, R.T. de; GONÇALVES, A.C.A.; JÁCOME, G.A.; REZENDE, R. Soil water balance simulated by CROPGRO-Drybean model for edaphoclimatic conditions in Maringá. Revista Brasileira de Engenharia Agrícola e Ambiental, Campina Grande, v.14, n.4, p.351-357, 2010.

DALLACORT, R.; FREITAS, P.S.L. de; FARIA, R.T.; GONCALVES, A.C.A.; REZENDE, R.; GUIMARÃES, R.M.L. Simulation of bean crop growth, evapotranspiration and yield in Paraná State by the CROPGRO-Dry bean model. Acta Scientiarum Agronomy, Maringá, v.33, n.3, p.429-436, 2011.

DALLACORT, R.; REZENDE, R.; FREITAS, P.S.L. de; FARIA, R.T. de; AZEVEDO, T.L. de F.; TELENTINO JÚNIOR, J.B. Utilização do modelo Cropgro-drybean na determinação das melhores épocas de semeadura da cultura do feijão para a região de Maringá, Estado do Paraná, Brasil. Acta Scientiarum Agronomy, Maringá, v.27, n.2, p.349-355, 2005.

FARIA, R.T. de; BOWEN, W.T. Evaluation of DSSAT soil-water balance module mnder cropped and bare soil conditions. Brazilian Archives of Biology and Technology, Curitiba, v.46, n.4, p.489-498, 2003.

FARIA, R.T. de; OLIVEIRA, D.; HOOGENBOOM, G. Drybeans development and yield simulation by CROPGRO . Annual Report of the Bean Improvement Cooperative, Michigan State University, East Lansing, v.45, n.1, p.132-133, 2002.

GOMES, A.W.A.; SAAD, J.C.C.; BARROS, A.C. Simulação da produtividade de cana-de-açúcar (Saccharum officinarum L.) na região Nordeste do Brasil, utilizando o modelo DSSAT. Irriga, Botucatu, v.19, n.1, p.160-173, 2014.

HOOGENBOOM, G.J.W.; JONES, P.W.; WILKENS, C.H.; PORTER, K.J.; BOOTE, L.A.; HUNT, U.; SINGH, J.L.; LIZASO, J.W.; WHITE, O.; URYASEV, F.S.; ROYCE, R.; OGOSHI, A.J.; GIJSMAN, G.Y.; TSUJI, AND J. KOO. Decision support system for agrotechnology transfer: version 4.5. Honolulu: University of Hawaii, 2012. CD-ROM.

LARA, M.A.; PEDREIRA, C.G.; BOOTE, K.J.; PEDREIRA, B.C.; MORENO, L.S.; ALDERMAN, P.D. Predicting growth of Panicum maximum: An adaptation of the CROPGROPerennial Forage Model. Agronomy Journal, Madison, v.104, n.3, p. 600-611, 2012.

LIMA FILHO, A.F.; COELHO FILHO, M.A.; HEINEMANN, A.B. Determinação de épocas de semeadura do feijão caupi no Recôncavo Baiano através do modelo CROPGRO. Revista Brasileira de Engenharia Agrícola e Ambiental, Campina Grande, v.17, n.12, p.1294-1300, 2013. 
LIU, H.L.; YANG, J.Y.; TAN, C.S.; DRURY, C.F.; REYNOLDS, W.D.; ZHANG, T.Q.; BAI, Y.L.; JIN, J.; HE, P.; HOOGENBOOM, G. Simulating water content, crop yield and nitrate-N loss under free and controlled tile drainage with subsurface irrigation using the DSSAT model.

Agricultural Water Management, Amsterdam, v.98, n.6, p.1105-1111, 2011.

LOPES, A. da S. Manejo do solo e da irrigação da cultura do feijoeiro sob pivô central. 2006. 141f. Tese (Doutorado) - Faculdade de Ciências Agrárias e Veterinárias, Jaboticabal, Universidade Estadual Paulista, Jaboticabal, 2006.

MARIN, F.R.; SINGELS, A.; ROYCE, F.; ASSAD, E.D.; PELLEGRINO, G.Q.; JUSTINO, F. Climate change impacts on sugarcane attainable yield in Southern Brazil. Climatic Change, Dordrecht, v. 117, n. 1-2, p. 227-239, 2013.

MEIRELES, E.J.L.; PEREIRA, A.P.; SENTELHAS, P.C.; STONE, L.F.; ZIMMERMANN, F.J.P. Calibration and test of the cropgro-dry bean model for edaphoclimatic conditions in 402 the savannas of central Brazil. Scientia Agricola, Piracicaba, v.59, n.4, p.723-729, 2002.

NASSIF, D.S.P.; MARIN, F.R.; PALLONE FILHO, W.J.; RESENDE, R.S.; PELLEGRINO, G.O. Parametrização e avaliação do modelo DSSAT/Canegro para variedades brasileiras de cana-deaçúcar. Pesquisa agropecuária brasileira, Brasília, v.47, n.3, p.311-318, 2012.

OLIVEIRA, E.C. de; COSTA, J.M.N. da; PAULA JÚNIOR, T.J. de; FERREIRA, W.P.M.; JUSTINO, F.B.; NEVES, L. de O. The performance of the CROPGRO model for bean (Phaseolus vulgaris L.) yield simulation. Acta Scientiarum. Agronomy, Maringá, v.34, n.3, p.239-246, 2012.

PEDREIRA, B.C.; PEDREIRA, C.G.S.; BOOTE, K.J.; LARA, M.A.S.; ALDERMAN, P.D. Adapting the CROPGRO perennial forage model to predict growth of Brachiaria brizantha. Field Crops Research, Amsterdam, v.120, n.3, p.370-379, 2011.

RODRIGUES, R. de A.; PEDRINI, J.E.; FRAISSE, C.W.; FERNANDES, J.M.C.; JUSTINO, F.B.; HEINEMANN, A.B.; COSTA, L.C.; VALE, F.X.R. do. Utilization of the cropgro-soybean model to estimate yield loss caused by Asian rust in cultivars with different cycle. Bragantia, Campinas, v.71, n.2, p.308-317, 2012.

WILLMOTT, C.J.; MATSUURA, K. Advantages of the mean absolute error (MAE) over the root mean square error (RMSE) in assessing average model performance. Climate Research, Oldendorff, v. 30, p. 79-82, 2005. 